\title{
Error Correction Model Analysis in Measuring the Effect of Bank Internal Factors on Mudharabah Deposits for Islamic Commercial Banks
}

\author{
Yudhistira Ardana*, Nur Syamsiyah, Misfi Laili Rohmi, Lilis Renfiana \\ Islamic Economics, Metro State Islamic Institute, Lampung Indonesia \\ * Correspondence email: yudhistiraardana@metrouniv.ac.id
}

\begin{tabular}{ll}
\hline Article Info & Abstract \\
& Islamic bank products to raise public funds can be in the form of \\
Keywords: & demand deposits (wadiah), savings (mudharabah), and deposits \\
Bank Internal Factors; & (mudharabah). One of the profit-sharing rates in Islamic banks \\
Mudharabah Deposits; & comes from internal factors, namely Return on Assets, Capital \\
Sharia Commercial Bank. & Adequacy Ratio, Financing to Deposit Ratio, and Operational \\
& Expenses Operating Costs. This study will examine the effect of \\
& bank internal factors on mudharabah deposits of Islamic \\
DOI: & commercial banks using an econometric model, namely the error \\
$10.33830 /$ elqish.v1i1.1518.2021 & correction model. Findings. The results showed that the bank's \\
& internal variables had a significant effect on mudharabah deposits \\
& both in the short and long term. Variables Return on Assets, Capital \\
& Adequacy Ratio, and Operational Expenses Operational costs both \\
& short and long term have a negative effect on mudharabah deposits. \\
\hline
\end{tabular}

\section{Introduction}

Globalization, liberalization, and privatization have paved the way for the expansion of the financial sector. Commercial banks are key players of the financial system in the creation of money in the economy. They turn savings into investment and contribute to capital formation in the economy. Islamic banks also play an important role in the development of several economies. In line with this, there has been a tremendous growth of Islamic banks to boost the financial system in many parts of the world. From 2008 until now, the world banking system has experienced several challenges due to the global economic recession trend. The banking sector has undergone many changes and faced great challenges in recent years in various parts of the world due to the recession trend. Several conventional banks in the US and European economies had to close due to the financial downturn. Shareholders such as owners, investors, debtors, creditors, government, depositors, bank managers, and regulators pay more attention to the financial performance of banks. Islamic banks are no exception to this downward trend despite widespread claims that Islamic banking fundamentals and conceptual frameworks have supported these institutions from serious failure and financial damage.

Normatively, companies that run their operations based on sharia must be motivated by the willingness of every Muslim to gain success in this world and the hereafter which is commonly called Falah. The concept of falah should be implemented in the form of all activities aimed at creating individual and social benefits. In Islamic teachings, there is the concept of maqasid sharia as the goal of applicable Islamic law. Maqasid sharia emphasizes the protection of religion (din), intellect ('aql), life (nafs), lineage (nasl), and wealth (māl). Islamic banks in their operations must pay attention to maqasid in their business activities, especially the protection and improvement of asset quality as well as all goods and services that have economic value.

Islamic banking was established in Indonesia because of the desire of investors to avoid usury contained in the interest system. Indonesian people are increasingly aware of the principles 
of their religion in all aspects of life, especially in economic matters which encourage them to start looking for solutions to meet their needs both in terms of investment and capital adequacy through legal means or interest-free practices. In other words, the existence of Islamic banks as an alternative solution to these problems is the conflict between bank interest as usury, so that the basic difference between conventional banks and Islamic banks is the prohibition of interest according to Islamic banks as the interest rate system adopted by conventional banks. Islamic banks in carrying out their operational activities are based on Islamic law that adheres to a profitsharing system. Sharia commercial banks are financial institutions that function to facilitate economic mechanisms in the real sector through business activities (investment, buying, and selling, etc.) based on sharia principles. Sharia principles are based on Islamic legal agreements between banks and other parties to deposit funds and/or fund business activities following sharia macro and microeconomic values.

The characteristics of the sharia banking system that operates are based on the principle of profit-sharing which provides an alternative banking system that is mutually beneficial to the public and the banking system, as well as prioritizing aspects of fairness in transactions, investment ethics, promoting the values of togetherness and brotherhood in production, and avoiding speculative activities in transactions. finance by providing various banking products and services. With more varied financial schemes, Islamic banking is an alternative to a credible banking system that can be sought by all levels of Indonesian society without exception. Based on this, then the income from depositing funds is not based on a set percentage (interest) but is determined in the form of a profit-sharing ratio to the income earned (Novianti et al, 2015). Thus, the consequence of this system is that the money earned from managing funds still depends on the income received (Sri et al, 2013).

(Daulay, 2010) states, profit sharing is one of the factors that influence the customer's desire to save their funds in Islamic banks. The high level of profit-sharing of an Islamic bank will increase the number of customers who save in the Islamic bank. Conversely, a decrease in the rate of profit sharing will have an impact on reducing customer interest in saving their funds in Islamic banks. Based on data from the 2020 OJK annual report, the development of mudharabah deposit accounts has increased every year. In 2017 there were 338 accounts, then in 2018 there were 374, and in 2019 there were 465 accounts. Conventional economists believe that depositors are attracted to deposit their money in banks because the opportunity cost of holding cash is high when interest rates are also high (Romer, 2001; Athukorala and Sen, 2004). This can be easily explained by the utility maximization (cost minimization) premise, as depositors will choose the course of action that will maximize their well-being or satisfaction. Several questions that arise related to whether Islamic bank depositors are also motivated by a high rate of return, at least this is answered by the results of research by Gerrard and Cunningham (1997), Metawa and Almossawi (1998), Haron and Ahmad (2000), and Ghafur (2003).

Gerrard and Cunningham (1997) find that in a non-Muslim majority country such as Singapore, Muslims still maintain their faith so they "will keep their deposits in Islamic banks. Even if the Islamic bank where they deposit money does not make a profit in one year" (Gerrard and Cunningham, 1997). However, they suggest that Islamic banks should seek profit, as $20.7 \%$ of Muslim respondents think that they will withdraw their deposits if "Islamic banks do not generate sufficient profit for distribution for approximately one year" (Gerrard and Cunningham, 1997).

Metawa and Almossawi (1998) found different conclusions from Gerrard and Cunningham (1997). Metawa and Almossawi (1997) conducted a study in Bahrain and found that depositors' bank selection decisions were primarily religious-based, followed by the rate of return. It can be 
said that in a country where the majority of the population is Muslim, such as Bahrain, the rate of return is not the main variable that affects the volume of deposits in Islamic banks.

Then Haron and Ahmad (2000) argue that depositors are still motivated by returns. Using the Adaptive Expectation Model (AEM), they find that depositors are indeed motivated by returns in Malaysia. Their estimation results show that a one percent increase in the rate of return granted to interest-free deposits is seen to increase the total amount of these deposits by 71 million Malaysian Ringgit and that conventional bank interest rates have a negative relationship with Islamic bank deposits, meaning that a one percent increase in conventional bank interest rates will reduce the interest-free investment deposit rate by 65 million Malaysian Ringgit (Haron and Ahmad, 2000). This means that conventional banks are still a compliment, not a substitute, in Malaysia. This finding is inconsistent with that found by Mettawa and Almossawi, although both studies were conducted in Muslim countries. The high level of profit-sharing certainly has factors that can influence it, namely internal and external factors. In this study, only using internal factors. Internal factors that affect the rate of profit sharing on mudharabah deposits include Return on Assets (ROA), Operating Costs to Operating Income (BOPO), Capital Adequacy Ratio (CAR), Financing to Deposits Ratio (FDR), and so on.

The results of the study (Maris, 2017) show that the ROA variable has no significant positive effect on mudharabah deposits. The results of this study are supported by research (Fadilawati \& Fitri, 2019; Ayufianti \& Suprayogi, 2020). Meanwhile, research (Sabtatianto \& Yusuf, 2018) explains that ROA has a significant positive effect on mudharabah deposits. The research was supported by (Nofianti et al, 2015; Harfiah et al, 2016; Purwati \& Wicaksana, 2019; Susanto, 2019; Sulfiyani \& Mais, 2019; Pasaribu et al, 2019). Farianto (2014) found that ROA had a significant negative effect on mudharabah deposits. Likewise with the results of research by Faza and Laily (2018).

Research (Mariss, 2017) shows that the CAR variable has a significant negative effect on mudharabah deposits. These results are supported by research (Sabtatianto \& Yusuf, 2018; Ayufianti \& Suprayogi, 2020; Yulinartati et al, 2020). Different research was produced by (Anwar \& Miqdad, 2017) which stated that CAR had a significant positive effect.

Research (Mariss, 2017) shows that the BOPO variable has a positive and insignificant effect on mudharabah deposits. These results are supported (Nofianti et al, 2015; Purwati \& Wicaksana, 2019). Meanwhile, the results of the study (Sabtatianto \& Yusuf, 2018; Sulfiyani \& Mais, 2019) had an insignificant negative effect. Different research results were obtained (Harfiah et al, 2016), where BOPO had a significant positive effect on mudharabah deposits. These results are supported by research results (Pasaribu et al, 2019). Different studies were also produced (Fadilawati \& Fitri, 2019) which stated that BOPO had a significant negative effect. This research is supported by research results (Ayufianti \& Suprayogi, 2020; Yulinartati et al, 2020). Research (Mariss, 2017) shows that the FDR variable has a significant positive effect on mudharabah deposits. These results are supported by research (Nofianti et al, 2015; Harfiah et al, 2016, Fadilawati \& Fitri 2019; Ayufianti \& Suprayogi, 2020; Yulinartati et al, 2020).

Research (Sabtatianto \& Yusuf, 2018) FDR has no significant positive effect. These results are supported by research (Pasaribu et al, 2019; Susanto, 2019). While the results of the study (Sulfiyani \& Mais, 2019 ), FDR had a negative and insignificant effect. From the explanation in the background, it can be seen that the results of the research conducted are still varied. For this reason, the authors are interested in further research under the explanation on the background to examine the effect of internal variables on mudharabah deposits using the Error Correction Model. 


\section{Research Method}

Analysis of the influence of internal variables on mudharabah deposits is seen using several variables, namely Mudharabah Deposits (DPS), Return on Assets (ROA), Operational Costs to Operating Income (BOPO), Capital Adequacy Ratio (CAR), Financing to Deposits Ratio (FDR). The form of long-term regression results is as follows.

$$
\mathrm{DPS}=\beta 0+\beta 1 \mathrm{ROA} i t+\beta 2 \mathrm{BOPO} i t+\beta 3 \mathrm{CAR} i t+\beta 4 \mathrm{FDR} i t+\mathrm{RESIDit}
$$

ECM is one of the models used to correct the regression equations between individual variables that are not stationary so that they return to equilibrium in the long term, provided that these variables must be mutually integrated between variables (Ajija, et al. 2011). In this case, ECM serves to correct the short-term relationship to the long-run equilibrium which was introduced by Sargan and popularized by Engel and Granger. After all, variables pass the cointegration test, it will be processed into an ECM test. The ECM model is formed from the longrun residual equation. The long-term remainder is used for error correction (ECT) error correction. Which affects the short-run equation. The following is the form of the ECM model equation in this study:

$$
\partial \mathrm{DPS}=\beta 0+\beta 1 \mathrm{ROAit}-1+\beta 2 \mathrm{BOPOit}-1+\beta 3 \mathrm{CAR} i t-1+\beta 4 \mathrm{FDR} i t-1+\mathrm{ECT} i t-1
$$

The ECM model can be said to be valid if the cointegration variable is supported by a significant and negative ECT coefficient value. If the ECT coefficient has a positive effect, the direction of the variables used will be further away from long-term equilibrium so that the ECM model cannot be used. The type of data used in this study is secondary data in the form of time series and the form of monthly data for 2017-2019. The analytical method used in this study uses two analytical methods, namely descriptive statistics, and quantitative analysis. Descriptive statistics in this model aim to explain or describe the object of research by looking at the influence of internal variables on mudharabah deposits. After that, to strengthen the results of the descriptive statistical test, it was continued by using quantitative data analysis using the Error Correction Model (ECM). By using time series data, before estimating, the data is tested using the data stationarity test. This test aims to avoid false regression. According to Gujarati (2004) the use of data time series in research has several characteristics as follows: 1) Empirical study with data time series assumes that the data used/ underlying is stationary; 2) One of the reasons for the emergence of autocorrelation in the use of data time series is the non-stationarity of the data. 3) Regressing a time series variable to variables time series others sometimes produce $\mathrm{R} 2$ high even though it's not there is a significant relationship between the two.

This situation is commonly called spurious regression or nonsense regression (false regression/no means); 4) Some data time series finance, sometimes following the phenomenon random walk. This means the best prediction for a time variable the series for the next time is the value of the variable days this is added error term/random shocks, 5) Regression using time series data is usually used to forecasting. The validity of this forecast will depend on the stationarity of the data time series used, and 7) The causality test is stationary. Therefore before doing this causality test data time series should be used stationary.

One way to identify the relationship between stationary variables is to make corrections to modeling errors. However, if there is cointegration of non-stationary data, then the error test is declared valid. This requirement is explained by the Engle-Granger theory (Ariefianto, 2012). 
Error Correction Model (ECM) is one of the estimation models used to test the regression equation between individual variables that are not stationary to return to equilibrium in the long term (Ajija, et al, 2011).

\section{Results and Discussions}

The first step to achieve the Error Correction Model test is the unit root test. In this research, it will be tested using Augmented Dickey-Fuller.

Table 1. ADF test

\begin{tabular}{lllllll}
\hline Variable & Level & & \multicolumn{4}{c}{ 1st difference } \\
& ADF Test & Prob. & Ket & ADF Test & Prob. & Ket \\
\hline DPS & -2.681936 & 0.0875 & Not Stationary & -5.787105 & 0.0000 & Stationary \\
ROA & -0.867821 & 0.7862 & Not Stationary & -5.416228 & 0.0001 & Stationary \\
BOPO & -1.092173 & 0.7075 & Not Stationary & -5.345360 & 0.0001 & Stationary \\
CAR & -0.933706 & 0.7650 & Not Stationary & 5.021324 & 0.0003 & Stationary \\
FDR & -3.374545 & 0.0191 & Stationary & - & - & - \\
\hline
\end{tabular}

Table 1 can be explained that overall the stationary variables at the 1 st difference level are DPA, ROA, BOPO, and CAR. Meanwhile, the variable that is stationary at the level is only FDR. This can be explained by the results of the ADF probability value which is less than $0.05(5 \%)$. After testing the stationarity of the data, the next step is to perform a cointegration test between variables.

Table 2. Johansen's Test

\begin{tabular}{lllll}
\hline $\begin{array}{l}\text { Hypothesized } \\
\text { No. of CE(s) }\end{array}$ & Eigenvalue & $\begin{array}{l}\text { Trace } \\
\text { Statistics }\end{array}$ & $\begin{array}{l}\mathbf{0 . 0 5} \\
\text { Critical Value }\end{array}$ & Prob.** \\
\hline None $*$ & 0.621355 & 70.52154 & 69.81889 & 0.0439 \\
At most 1 & 0.469125 & 38.47335 & 47.85613 & 0.2818 \\
At most 2 & 0.313360 & 17.57679 & 29.79707 & 0.5974 \\
At most 3 & 0.130131 & 5.170603 & 15.49471 & 0.7905 \\
At most 4 & 0.017124 & 0.569986 & 3.841466 & 0.4503 \\
\hline
\end{tabular}

Johansen's test results in table 2 can be explained that there is at least one trace statistic value that is more than the critical value, namely $70.52154>69.81889$. It can be concluded that all variables have a long-term effect. 
Table 3. ECM Test (Long Term)

\begin{tabular}{lllll}
\hline Variable & Coefficient & Std.Error & T-Statistic & Prob. \\
\hline C & 223456.9 & 2232147. & 0.100109 & 0.9209 \\
CAR & -727.8566 & 1098,274 & -0.662728 & 0.5126 \\
BOPO & -471.6534 & 240.6923 & -1.959571 & 0.0594 \\
ROA & -280061.8 & 224600.5 & -1.246933 & 0.2221 \\
FDR & 650.8758 & 241.0598 & 2.700059 & 0.0113 \\
R-squared & 0.335628 & F-statistics & & 3.788862 \\
Adjusted R-squared & 0.247045 & Prob(F-statistic) & 0.013086 \\
\hline
\end{tabular}

The results of the long-term ECM test in table 3 can be explained that overall it can be concluded that the variables used in this study have a significant effect. This can be indicated by a probability value that is less than the $5 \%$ significance level $(0.013086<0.05)$. The percentage of the effect of variable $\mathrm{X}$ on $\mathrm{Y}$ is $24.70 \%$ (as seen from the Adjusted R-squared value of 0.247045 . Furthermore, if analyzed partially, there are only two variables that have a significant effect on mudharabah deposits, namely FDR and BOPO. While CAR and ROA have no effect To test whether the model we use is strong or not by testing the Error Correction Term (ECT) on the model.

Table 4. ECT test

\begin{tabular}{lccc}
\hline & & t-Statistic & Prob.* \\
\hline Augmented Dickey-Fuller test statistics & -3.584489 & 0.0115 \\
Test critical values: & $1 \%$ level & -3.639407 & \\
& $5 \%$ level & -2.951125 & \\
$10 \%$ level & -2.614300 & \\
\hline
\end{tabular}

The ECT test results in table 3 produce a probability value of less than $5 \%(0.0115<0.05)$, meaning that the model built in this study is strong and there is a short-term relationship.

Table 5. ECM Test (Short Term)

\begin{tabular}{lllll}
\hline Variable & Coefficient & Std.Error & T-Statistic & Prob. \\
\hline C & $-1854,683$ & 44440.67 & -0.041734 & 0.9670 \\
D(CAR) & -1729.059 & 2197,090 & -0.786977 & 0.4379 \\
D(BOPO) & -491.2300 & 411.1266 & -1.194839 & 0.2422 \\
D(ROA) & -315669.5 & 266552.5 & -1.184267 & 0.2463 \\
D(FDR) & 534.7758 & 197.2614 & 2.711001 & 0.0113 \\
ECT-1 & 0.601085 & 0.180683 & 3.326744 & 0.0025 \\
R-squared & 0.461754 & F-statistics & & 4.804173 \\
Adjusted R-squared & 0.365639 & Prob(F-statistic) & & 0.002697 \\
\hline
\end{tabular}


In the short-term ECM test results in table 4, it is also found that overall in the short-term the variables used in this study have a significant effect overall. This can be explained by the results of the probability value which is less than $5 \%(0.002697<0.05)$. Meanwhile, in the short term, the ability of variable $\mathrm{X}$ to affect variable $\mathrm{Y}$ (mudharabah deposits) is $36.56 \%$. This figure can be seen from the adjusted R-squared value, which is 0.365639 . Partially, only the FDR variable has a significant effect on mudharabah deposits, while others, namely CAR, BOPO, and ROA in the short term have no significant effect.

Based on short-term and long-term estimates, it can be concluded that the CAR variable in the short term obtained a t-statistic result of -0.786977 and a probability value of 0.4379 . In the short term, these results can be explained that every $1 \%$ increase in CAR, there will be a decrease of 0.786977 in mudharabah deposits and vice versa. In the short term, the CAR variable has no significant negative effect because the probability value is more than $5 \%(0.4379>0.05)$. In the long run, the $t$-statistic result is -0.662728 and the probability value is 0.5126 . These results can be explained that every $1 \%$ increase in CAR, there will be a decrease of 0.662728 in mudharabah deposits and vice versa. In the long term, the CAR has no significant negative effect because the probability value is more than $5 \%(0.5126>0.05)$. This could happen, considering that some Islamic commercial banks still have a CAR value of up to $70 \%$.

The precautionary principle applied by Islamic banks makes policymakers make rules that are sometimes not per the rules set by the government. This means that there are still Islamic banks that have a high CAR due to anticipating unwanted risks, including in terms of managing loans from third-party funds. It is intended that Islamic banks can pay to third parties to be guaranteed and the risk of not being able to return Islamic banks to be small. In addition, the high CAR in Islamic banks can hinder the expansion of the business of Islamic banks themselves. Because the revolving capital is not so large that in the end, it will affect the small mudharabah profit sharing. The results of this study are supported by Mariss (2017), Sabtatianto and Yusuf (2018), Ayufianti and Suprayogi (2020), and Yulinartati et al (2020) which show that the CAR variable harms mudharabah deposits. Because the revolving capital is not so large that in the end, it will affect the small mudharabah profit sharing. The results of this study are supported by Mariss (2017), Sabtatianto and Yusuf (2018), Ayufianti and Suprayogi (2020), and Yulinartati et al (2020) which show that the CAR variable harms mudharabah deposits. Because the revolving capital is not so large that in the end, it will affect the small mudharabah profit sharing. The results of this study are supported by Mariss (2017), Sabtatianto and Yusuf (2018), Ayufianti and Suprayogi (2020), and Yulinartati et al (2020) which show that the CAR variable harms mudharabah deposits.

The BOPO variable in the short term obtained a t-statistic result of -1.194839 and a probability value of 0.2422 . In the short term, these results can be explained that every $1 \%$ increase in BOPO, there will be a decrease of 1.194839 in mudharabah deposits and vice versa. In the short term, the BOPO variable has no significant negative effect because the probability value is more than $5 \%(0.2422>0.05)$. In the long run, the $t$-statistic result is -1.959571 and the probability value is 0.0594 . These results can be explained that every $1 \%$ increase in BOPO, there will be a decrease of 1.959571 in mudharabah deposits and vice versa. In the long term, BOPO has a significant negative effect because the probability value is less than $5 \%(0.0594<0.05)$. These results are by Andarini (2013)'s explanation which explains that a decreased BOPO will increase bank income.

If the operational costs of bank activities are high, it will have an impact on the distribution of profit-sharing on mudharabah deposits. This is due to the disproportionate comparison between operating income and operating costs so that it can lead to bank unhealthy indirectly which in turn will have an impact on the profit-sharing received by customers. The smaller the BOPO in Islamic banks shows that the financial performance is good. If, on the other hand, Islamic banks experience 
unfavorable financial conditions, the rate of profit-sharing for mudharabah deposits will also decrease. The results of this study are following the results of research by Fadilawati and Fitri (2019) Ayufianti and Suprayogi (2020), and Yulinartati et al (2020) which stated that BOPO had a significant negative effect.

ROA in the short term obtained a t-statistic result of -1.184267 and a probability value of 0.2463 . In the short term, these results can be explained that every $1 \%$ increase in ROA, there will be a decrease of 1.184267 in mudharabah deposits and vice versa. In the short term, the ROA variable has no significant negative effect because the probability value is more than $5 \%(0.2463$ $>0.05)$. In the long run, the $t$-statistic result is -1.246933 and the probability value is 0.2221 . These results can be explained that every $1 \%$ increase in ROA, there will be a decrease of 1.246933 in mudharabah deposits and vice versa. In the long term, ROA has no significant negative effect because the probability value is more than $5 \%(0.2221>0.05)$. The results of this study indicate that when ROA increases, mudharabah deposits decrease. This can happen because the income earned in the current year has not been reduced by the tax burden. The higher the income earned by a company, the higher the taxes that must be paid by the company, Islamic banks are no exception. So that the results of this study are appropriate because the total income earned after deducting taxes will automatically decrease, which is the net income after the imposition of the tax that will be distributed to customers, one of which is through profit-sharing on mudharabah deposits. In addition, the income earned during the current year has not been deducted from other operational costs, which in turn will have an impact on the decrease in the level of profit-sharing received by customers. These results are from the research of Farianto (2014) and Faza and Laily (2018) which obtained the results that ROA has a negative effect.

The FDR variable in the short term obtained a t-statistic result of 2.711001 and a probability value of 0.0113 . In the short term, these results can be explained that every time there is an increase in FDR of 1\%, there will be an increase of 1.194839 in mudharabah deposits and vice versa. In the short term, the FDR variable has a significant positive effect because the probability value is less than $5 \%(0.0113<0.05)$. In the long run, the $t$-statistic result is 2.700059 and the probability value is 0.0113 . These results can be explained that every $1 \%$ increase in BOPO, there will be an increase of 1.959571 in mudharabah deposits and vice versa. In the long term, FDR has a significant positive effect because the probability value is less than $5 \%(0.0113<0.05)$. The results of this study can be explained that, if the Islamic bank has a high FDR, then indirectly the Islamic bank is trying to increase the acquisition of its managed funds. One way that Islamic banks can do is with deposit products to attract customers with an attractive profit-sharing rate. It is hoped that with a high FDR, it is also expected to increase the amount of profit-sharing for mudharabah deposits that will be received by customers.

\section{Conclusions}

Based on the results of the research and discussion, the authors conclude that the variables used in this study, namely CAR, BOPO, ROA, and FDR have a significant effect on mudharabah deposits both in the short and long term. Variables CAR, BOPO, and ROA both short term and long term have a negative influence on mudharabah deposits. Meanwhile, FDR has a positive effect on mudharabah deposits. Looking at the research results in general, it is necessary for Islamic banks to aggressively promote Islamic banking products, especially mudharabah deposits so that customers who have excess funds can save the excess funds in the form of deposits at Islamic banks. Islamic banks are also required to always maintain their performance by utilizing various existing products, one of which is mudharabah deposits. With a higher number of bank 
profitability, plus a good level of liquidity, it is hoped that Islamic banks will be able to attract customers' interest and be able to compete with existing conventional banks.

\section{References}

Ajija, S. R, Wulandari, D., Setianto, RH, \& Primanthi. MR (2011). Smart Ways to Master Eviews. Jakarta: Salemba Empat

Andarini, IP 2013. The Effect of Financial Performance Persistence and Efficiency on Rate Of Return on Mudharabah Savings. Thesis of UIN Sunan Kalijaga. Yogyakarta.

Anwar, C., \& Miqdad, M. (2017). The Effect of Third Party Funds (TPF), Capital Adequacy Ratio (CAR), Return On Assets (ROA) on Mudharabah Financing at Islamic Commercial Banks in 2008 - 2012. OWNER Research \& Accounting Journal. 1(1), 4247.https://owner.polgan.ac.id/index.php/owner/article/view/14

Ariefianto, MD (2012.) Econometrics essence and application using EViews. Jakarta: Erlangga.

Athokorala, PC., and Sen, K. (2004). The Determinants of Private Saving in India. World Development. 32(3), 491-503.https://doi.org/10.1016/j.worlddev.2003.07.008

Ayufianti, NE, \& Suprayogi, N. (2019). Meta-Analysis: Variables Affecting Profit Sharing Rates for Mudharabah Deposits (Study on Islamic Commercial Banks in Indonesia). Journal of Theoretical and Applied Islamic Economics. 7(4), 646-658. two :http://dx.doi.org/10.20473/vol7iss20204pp646-658

Daulay, R. (2010). Analysis of Services and Profit Sharing on Customer Savings Decisions at Islamic Banks in Medan City. Journal of Management \& Business. 10(1). two :https://doi.org/10.30596/jrab.v12i1.91

Fadilawati, N., \& Fitri, M. (2019). The Effect of Return on Assets, Operational Costs on Operating Income, Financing To Deposit Ratio, and Non-Performing Financing on Profit Sharing Rates for Mudharabah Deposits (Empirical Study on Islamic Commercial Banks in Indonesia for the 2012-2015 Period). Scientific Journal of Accounting Economics Students (JIMEKA). 4(1), 87-97. two :https://doi.org/10.24815/jimeka.v4i1.110800

Farianto, A. (2014). Analysis of the Effect of Return on Assets (ROA), BOPO and BI Rate on Profit Sharing Rates for Mudharabah Deposits at Islamic Commercial Banks in Indonesia in 2012 - 2013. Journal of EQUILIBRIUM. Vol 2(1), 104-125. two :http://dx.doi.org/10.21043/equilibrium.v2i1.713

Faza, Z. \& Laily, UF (2018). The Effect of Return On Assets, Return On Equity, and Financing To Deposit Ratio on Profit Sharing Rates for Mudharabah Deposits (In Islamic Commercial Banks for the Period 2012-2017). El-Qist Journal. 8(1), 1597-1617. two :https://doi.org/10.15642/elqist.2018.8.1.1597-1617

Gerrard, P., and Cunningham, JB (1997). Islamic Banking: A Study in Singapore. The International Journal of Bank Marketing. 15(6), 204416.https://doi.org/10.1108/02652329710184433

Gujarati, DN (2013). Fundamentals of Econometrics, Fifth Edition. Mangunsong, RC, translator. Jakarta: Salemba Empat.

Harfiah, LM, Purwati, AS, \& Ulfah, P. (2016). The Impact Of ROA, BOPO, And FDR To Indonesian Islamic Bank's Mudharabah Deposit Profit Sharing. Journal of Ethics. 15(1), 1930. two :http://dx.doi.org/10.15408/etk.v15i1.3109

Haron, S., and Ahmad, N. (2000). The Effects of Conventional Interest Rates and Rate of Profit on Funds Deposited With Islamic Banking System in Malaysia. Journal of Islamic Financial Services. 1(4).http://www.iaif.ir/images/khareji/articles/bank/3.pdf 
Marris, E. 2017. The Effect of Return on Assets (ROA), BOPO, Financing to Deposit Ratio (FDR), Capital Adequacy Ratio (CAR) and Non-Performing Financing (NPF) on Profit Sharing Rates on Mudharabah Deposits at Islamic Commercial Banks in Indonesia ( period 20122015). STIE IBS Student Scientific Journal.http:// http://repository.ibs.ac.id/162/

Metawa, SA and Almossawi, A. (1998). Banking Behavior of Islamic Bank Customers: Perspectives and Implications. The International Journal of Bank Marketing. Vol 16 (7), 299313.https://doi.org/10.1108/02652329810246028

Novianti, N., Badina, T., \& Erlangga, A. (2015). Analysis of the Effect of Return on Assets (ROA), Operating Costs on Operating Income (BOPO), Interest Rates, Financing To Deposits Ratio (FDR) and Non Performing Financing (NPF) on Profit Sharing Rates for Mudharabah Deposits (Empirical Study on Islamic Commercial Banks in Indonesia 2011-2013). ESSENCE of Journal of Business and Management. 5(1), 65-86. two :http://dx.doi.org/10.15408/ess.v5i1.2333

Pasaribu, DSO, Irfan., \& Sari, M. (2019). The Effect of Financing to Deposit Ratio (FDR), Non Performing Financing (NPF), Profitability and Operational Cost of Operational Income (BOPO) on the Mudharabah Financing of Sharia Commercial Banks In Indonesia. PROCEEDING CelSciTech-UMRI. 25-29.https://ejurnal.umri.ac.id/index.php/PCST/ article/view/1746

Purwati, D. \& Wicaksana, RS (2019). Analysis of the Effect of Return on Assets (Roa), Bopo, and Bi-Rate on Profit Sharing Rates for Funding Products with Mudharabah Mutlaqah Contract Scheme (Study on Bank Syariah Mandiri Period 2011 - 2018). Aghniya Journal of Islamic Economics. 2(1), 384-396.http://jurnal.umsu.ac.id/index.php/AGHNIYA/article/view/3903 Romer, D. (2001). Advanced Macroeconomics, 2nd ed. McGrawHill

Sri, A., Anggraini, R., Gurendrawati, E., \& Hasanah, M. (2013). The Influence of Third-Party Funds, Car, Npf and Roa Against the Financing of A General Sharia-Based Bank in Indonesia. International Conference on Business, Economics, and Accounting, 20-23 March in Bangkok, Thailand.

Sabtatianto, R., \& Yusuf, M. (2018). The Influence of BOPO, CAR, FDR and ROA on the Profit Sharing Rate of Mudharabah Deposits at Islamic Commercial Banks in Indonesia (Study on Islamic Commercial Banks in Indonesia). ULTIMA Accounting. 10(2), 169-186. two :https://doi.org/10.31937/akuntansi.v10i2.978

Sulfiani, N., \& Mais, R. (2019). Analisis Pengaruh Kinerja Keuangan Terhadap Tingkat Bagi Hasil Deposito Mudharabah Pada Bank Umum Syariah Di Indonesia Tahun 2012-2018. Jurnal STEI Ekonomi, 28(01), 122 - 142. https://doi.org/10.36406/jemi.v28i01.263

Susanto, E. (2019). Analysis of the Effect of ROA, FDR, Capital, CAR on the Rate Of Return on Mudharabah Deposits at PT Bank Syariah Mandiri. Journal of Islamic Economics. 10(2), 138-151.https://journal.uhamka.ac.id/index.php/jei/article/view/3996

Yulinartati, Probowulan, D., \& Putri, DAA (2020). Factors Affecting the Profit Sharing Rate of Mudharabah Deposits at BMT Maslahah in Situbondo Regency.JEAM. 19(1), 61-76. two :https://doi.org/10.19184/jeam.v19i1.17608 